\title{
Isolation and Identification of Two Novel Escherichia coli Bacteriophages and Their Application in Wastewater Treatment and Coliform's Phage Therapy
}

\author{
Keivan Beheshti Maal ${ }^{1, *}$; Abbas Soleimani Delfan ${ }^{1}$; Sharareh Salmanizadeh ${ }^{1}$ \\ ${ }^{1}$ Department of Microbiology, Faculty of Biological Sciences, Falavarjan Branch, Islamic Azad University, Isfahan, IR Iran \\ ${ }^{*}$ Corresponding author: Keivan Beheshti Maal, Department of Microbiology, Faculty of Biological Sciences, Falavarjan Branch, Islamic Azad University, Falavarjan, Isfahan, IR Iran. Tel/ \\ Fax:+98-3137420136, E-mail: beheshtimaal@iaufala.ac.ir
}

Received: September 20, 2013; Revised: June 3, 2014; Accepted: November 25, 2014

\begin{abstract}
Background: Phage therapy or use of lytic bacteriophages for eliminating bacterial populations has been developed for several aspects of human affairs such as medicine, agriculture and food industries.

Objectives: The high load of coliforms of treated wastewater effluents that are discharged into the rivers or agricultural lands is a serious concern of the Iran Department of Environment and the reduction of coliforms using phages to overcome this problem is an asset. This research aimed to isolate and identify specific lytic coliphages and investigate their effects on native and standard Escherichia coli strains as well as coliform populations in municipal wastewater.

Materials and Methods: The wastewater sample was cultured on selective culture media to isolate a native coliform strain and characterized using molecular methods. River water was centrifuged and passed through a $0.45 \mu \mathrm{m}$ filter and its lytic coliphages were enriched and purified against a native E. coli as well as a standard E. coli strain. Municipal wastewater was treated with isolated lytic coliphages and most probable number(MPN) reduction was examined.

Results: E. coliSBSWF27, which is a native strain of E. coli from Isfahan municipal wastewater treatment plant, was isolatedand characterized. Also two novel bacteriophages related to Myoviridae and Podoviridae families of bacteriophages from Zayandehrood River (Isfahan, Iran) were isolated. These coliphages had lytic effects on E. coli PTCC1399 and E. coli SBSWF27 as coliform's index. The myovirus had a hexagonal head measuring $27.28 \mathrm{~nm}$ and a noncontractile tail measuring $204.5 \times 13.63 \mathrm{~nm}$. The podovirus had an oval head measuring $98 \times 35 \mathrm{~nm}$ and a tail, $14 \mathrm{~nm}$ in diameter. The treatment of municipal sewage with the coliphage mixture resulted in a 22 -fold decrease of the coliform's MPN from 2400 to 110 after two hours of incubation.

Conclusions: This is the first report on isolation and identification of two novel lytic myovirus and podovirus from Zayandehrood River in Isfahan that had lytic effects on E. coli PTCC1399 and E. coli SBSWF27 strains as well as coliform's population of Isfahan municipal wastewater. We suggest that the use of these lytic coliphages for reduction of coliform's population in sewage could be considered as an effective and simple alternative for costly replacement of instruments and establishments of the old wastewater treatment plants.
\end{abstract}

Keywords:Bacteriophages; Sampling Studies; WasteWater

\section{Background}

Among sewage pathogens, coliforms as facultative aerobic Gram negative rods that could ferment lactose at $35^{\circ} \mathrm{C}$, are responsible for frequent infectious diseases in human and animals. The use of treated wastewater as water resources for agricultural and industrial applications is an origin for reemergence and distribution of pathogenic bacteria (1). Amongst coliforms, Escherichia coli is a Gram-negative rod related to order Enterobacteriales and family Enterobacteriaceae. This microorganism is the most important agent for urinary and gastrointestinal infections in human. Also E. coli is the most valuable contamination index of water, food and agricultural products, indicating contamination with coliforms and wastewater (2). Bacteriophages are viruses that are significantly distributed in nature and specifically attack bacterial hosts $(3,4)$. Phage therapy or use of bacteriophages as therapeutic agents for eliminating bacte- rial infections was introduced by preliminary studies of Twort and D'Herelle at the first of the 20 th century $(5,6)$. Several studies have proved the usefulness of phage therapy for controlling infectious diseases caused by pathogenic bacteria such as E. coli in human children and adults (7), E. coli infections in mice and calves (8), Pseudomonas aeruginosa and Acinetobacter baumannii in skin infections (9), oral streptococci in dental infections $(4,10)$, Staphylococcus aureus and S. epidermidis in skin infections (6) and Vibrio cholera infections (5). While most studies have focused on the potential of bacteriophages for controlling bacterial pathogens in medical microbiology, there are a few reports indicating the application of phages in wastewater treatment and environmental microbiology $(11,12)$.

Mixture of bacteriophages has been applied for eliminating pathogenic bacteria such as Salmonella enterica

Copyright (c) 2015, Ahvaz Jundishapur University of Medical Sciences. This is an open-access article distributed under the terms of the Creative Commons Attribution-NonCommercial 4.0 International License (http://creativecommons.org/licenses/by-nc/4.0/) which permits copy and redistribute the material just in noncommercial usages, provided the original work is properly cited. 
in compost (13). Recently, bacteriophages have been used for removal of hospital wastewater pathogens such as Pseudomonas spp., Streptococcus spp., Bacillus spp. and antibiotic resistant E. coli (14). Bacteriophages are the most abundant microorganisms in aquatic environments and play a critical role in keeping host populations, such as algae, fungi and bacteria, under control, thus they could be used for the elimination of environmental microorganisms considered as public health threats (15).

\section{Objectives}

One of the most concerning problems of Iranian wastewater treatment plants (WWTP) that has been highlighted by the Iran Department of Environment, is the high load of coliforms in treated wastewater effluents that are discharged into the rivers or agricultural lands. To address this problem we focused on the control of enterobacteria using their specific bacteriophages. The aims of this research were to isolate and identify native strains of E. coli from wastewater, as well as specific lytic coliphages from water resources, and to investigate the effects of these coliphages on native and standard E. coli strains and coliform populations in municipal wastewater.

\section{Materials and Methods}

\subsection{Bacterial Strains and Culture Media}

The bacterial strains used in this research were E. coli PTCC1399, which was provided by the Iranian Research Organization for Science and Technology (IROST) (Tehran, Iran), and a native strain of E. coli, which was isolated as part of this research. The main culture media were eosin methylene blue (EMB), lactose broth (LB), brain heart infusion broth (BHI) and brain heart infusion agar (BHA), all from Merck, Germany.

\subsection{Wastewater Sampling and Bacterial Isolation}

The sewage sample was gathered from sewage effluents before treatment at Isfahan southern wastewater treatment plant (Isfahan, Iran), using sterile $1000 \mathrm{~mL}$ capped bottles under aseptic conditions. The samples were transferred to the microbiology laboratory of the Falavarjan Branch of Islamic Azad University (Falavarjan, Iran), at $4^{\circ} \mathrm{C}$. One milliliter of sewage effluent was cultured in $\mathrm{LB}$ and incubated at $37^{\circ} \mathrm{C}$ for 24 hours. One standard loop from the positive LB medium was cultured in EMB using the streak plate method and incubated at $37^{\circ} \mathrm{C}$ for 24 hours. A well isolated violet colony with metallic greenish reflection was collected and cultured on EMB and incubated for 24 hours at $37^{\circ} \mathrm{C}$ for purification purposes. The purified bacteria on EMB were stained using the Gram stain kit (Taligene Pars Co., Iran) (4-15).

\subsection{DNA Extraction and Molecular Identification of Isolated Bacterium}

A well-isolated colony on EMB was cultured in $100 \mathrm{~mL}$ of $\mathrm{BHI}$ and incubated at $37^{\circ} \mathrm{C}$ with $120 \mathrm{rpm}$ (rounds per minute) aeration speed for 24 hours. Forty milliliters of bacteria in BHI was transferred to a $50 \mathrm{~mL}$ sterile falcon tube and centrifuged at $8000 \mathrm{~g}$ for 10 minutes. The supernatant was discarded and $10 \mathrm{mg}$ of bacterial biomass was used for DNA extraction using a DNA extraction kit for Gram-negative bacteria (Cinnagen, Iran, Cat. \# DN8115C), according to the manufacturer's instructions.

The primers used for molecular identification of the isolated coliform strain (high performance universal primers for bacterial identification) were RW01 as the forward primer with the sequence of 5'AACTGGAGGAAGGTGGGGAT3' and DG74 as the reverse primer with the sequence of 5'AGGAGGTGATCCAACCGCA3'. The expected molecular weight of the PCR product using these primers was $370 \mathrm{bp}$ (16). The PCR was performed in 20 $\mu \mathrm{L}$ of a reaction mixture. The PCR product and primers were sent to Macrogene Co., South Korea for DNA sequencing. The DNA sequence was reviewed using Finch TV and Mega 4 softwares and its similarity to GenBank genomic sequences was investigated using the BLAST software (http://blast.ncbi.nlm.nih.gov). The isolated strain was identified after bioinformatics analysis (3).

\subsection{Isolation of Bacteriophages From Possible Re- sources}

The water of Zayandehrood River (Isfahan, Iran), as a probable origin of bacteriophages was used. This water was gathered using $500 \mathrm{~mL}$ sterile capped bottles. The bottles were opened in $30 \mathrm{~cm}$ of the inframarine surface and sampling was done for five minutes. The bottles were closed under the water and transferred at $4^{\circ} \mathrm{C}$ to the microbiology laboratory of the Falavarjan Branch of Islamic Azad University (Falavarjan, Isfahan, Iran) $(4,10)$.

\subsection{Bacteriophage Enrichment and Isolation}

The water of Zayandehrood River was centrifuged at $8000 \mathrm{~g}$ for 10 minutes and the supernatant was filter sterilized using a $0.45 \mu \mathrm{m}$ membrane filter. Ten milliliters of the filtrate was added to each of the $40 \mathrm{~mL}$ sterile BHI flasks followed by contaminating of flasks with $100 \mu \mathrm{L}$ of isolated coliform, Escherichia coli SBSWF27 and Escherichia coli PTCC1399. The two BHI flasks were cultured using $100 \mu \mathrm{L}$ of the same strains without adding river filtrates as negative controls. The BHI media were incubated at $37^{\circ} \mathrm{C}$ for 24 hours with aeration speed of 120 rpm for bacteriophage enrichment. Ten milliliters from each flask was transferred to $15 \mathrm{~mL}$ sterile falcons and centrifuged at $8000 \mathrm{~g}$ for 10 minutes. The supernatant was passed through $0.45 \mu \mathrm{m}$ syringe filters and stored at $4^{\circ} \mathrm{C}$ for the next step. One hundred microliters of each E. coli strain, SBSWF27 and E. PTCC1399, were cultured on 
BHA media using the spread plate method and incubated at $37^{\circ} \mathrm{C}$ for two hours. Next, $20 \mu \mathrm{L}$ of phage filtrate at dilutions of $10^{-1}$ to $10^{-7}$ were dropped on specified zones in bacterial lawns and incubated at $37^{\circ} \mathrm{C}$ for 24 hours (3, $10,13)$.

\subsection{Identification of Coliphages Using Transmis- sion Electron Microscopy}

One BHA plate containing the phage plaques was selected and the top agar was crashed using a sterile tip. Ten milliliters of SM buffer was added to the plate and washed carefully. The crashed top agar and SM buffer was transferred to a $15 \mathrm{~mL}$ sterile falcon and centrifuged at $8000 \mathrm{~g}$ for 10 minutes. The supernatant was passed through the $0.45 \mu \mathrm{m}$ syringe filter. One drop of filtrate was transferred to a formvar grid (EM standard, $3.2 \mathrm{~mm}$ ) and negatively stained with uranyl acetate $2 \%(\mathrm{w} / \mathrm{v})$ solution ( $\mathrm{pH}$ : 4-4.5). The grid was observed using a transmission electron microscope (Philips, CM10) with $78 \mathrm{~K}$ magnification (4-9).

\subsection{Bacterial Growth Curve Before and After Treatment with Lytic Bacteriophages}

For determining the growth curve of E. coli SBSWF27 and PTCC1399, $500 \mu \mathrm{L}$ of each of the overnight cultures were added to $50 \mathrm{~mL}$ of $\mathrm{BHI}$ and incubated at $37^{\circ} \mathrm{C}$ with aeration speed of 120 rpm for 30 hours. The optical density (OD) of medium was measured at $600 \mathrm{~nm}$ at threehour intervals. For determining the growth curve of bacteria in the presence of lytic bacteriophages, $500 \mu \mathrm{L}$ of overnight culture was added to $50 \mathrm{~mL}$ of BHI. Next, $500 \mu \mathrm{L}$ of purified phage, with titration of $3.3 \times 10^{9} / \mathrm{mL}$, was added to BHI and incubated with the same conditions. The optical density (OD) of the medium was measured as previously described (13-15).

\subsection{Effect of Coliphages on Sewage Coliform's Load}

The most probable number (MPN) of $100 \mathrm{~mL}$ of Isfahan's municipal wastewater was measured, using three sets of five Durham tubes containing LB media, after 120 minutes of incubation at $37^{\circ} \mathrm{C}$. To evaluate coliphages for coliform removal and MPN reduction, $1 \mathrm{~mL}$ of purified coliphages with titration of $3.3 \times 10^{9} / \mathrm{mL}$ was added to $100 \mathrm{~mL}$ of municipal wastewater and incubated at $37^{\circ} \mathrm{C}$ for two hours. Then the MPN of phage-treated wastewater was measured using the same method. For obtaining a more realistic result, in the next step, 100 $\mathrm{mL}$ of Isfahan's municipal wastewater was mixed with $1 \mathrm{~mL}$ of coliphage at titration of $3.3 \times 10^{9} / \mathrm{mL}$ and placed in a room with fluctuating temperatures of $22^{\circ} \mathrm{C} \pm 5^{\circ} \mathrm{C}$ without any aeration for two to six hours. The MPN of phage-treated wastewater was measured after two, four and six hours of treatment using the same method (1719).

\section{Results}

The presence of coliforms, after three stages of presumptive, confirmed and completed coliform tests in Isfahan's municipal wastewater sample, was confirmed. The growth of bacteria and turbidity along with gas accumulation in lactose broth media after 24 hours of incubation at $37^{\circ} \mathrm{C}$ showed that the presumptive test was positive. Cultivation of LB media (with gas and turbidity) on EMB after incubation at $37^{\circ} \mathrm{C}$ for 24 hours showed that the confirmed test was positive. The presence of pure Gram negative rods in the microscopic slides showed that the completed test was positive. The PCR of purified bacterial DNA with universal primers showed a $370 \mathrm{bp}$ band on the gel. The BLAST analysis of the genomic sequence of 16s-rDNA confirmed that the isolated strain from Isfahan wastewater sample was $E$. coli with $92 \%$ query coverage, $99 \%$ similarity and E-value of $8 \mathrm{e}-82$ in comparison with E. coli BDUJN17 (accession \# KC985144.1). This strain was named E. coli SBSWF27 and its genomic sequence has been submitted to GenBank with temporary accession number JN836931.

The addition of Zayandehrood River filtrate to E. coli SBSWF27 and E. coli PTCC1399 in BHI culture media resulted in complete clearance of BHI after 24 hours of incubation at $37^{\circ} \mathrm{C}$. Spotting the enriched bacteriophage filtrate on the mix culture of E. coli SBSWF27 and E. coli PTCC1399 on BHA showed big phage plaques after overnight incubation at $37^{\circ} \mathrm{C}$ (Figure 1). The growth curve of E. coli PTCC1399 before and after treatment with specific lytic bacteriophages during 30 hours of incubation at $37^{\circ} \mathrm{C}$ showed that the isolated specific coliphages could inhibit the normal growth of bacterium (Figure 2). Also, the growth curve of E. coli SBSWF27 after treatment with isolated coliphages during 30 hours of incubation at $37^{\circ} \mathrm{C}$ showed that the coliphages prevented the normal growth of E. coli SBSWF27 (Figure 3). Transmission electron microscopy of purified phage solution isolated from the mix culture of both E. coli PTCC1399 and E. coli SBSWF27 showed two types of lytic bacteriophages. The first lytic coliphage had a small hexagonal head with diameter of $27.28 \mathrm{~nm}$ and a long noncontractile tail measuring $204.5 \mathrm{~nm}$ in length and $13.63 \mathrm{~nm}$ in diameter. According to its size and morphology, it was suggested that the first isolated coliphage was most probably related to the Myoviridae family of bacteriophages (Figure $4 \mathrm{~A}$ ). The second lytic bacteriophage had an oval head measuring $98 \times 35 \mathrm{~nm}$ and a small tail measuring $14 \times$ $14 \mathrm{~nm}$. According to transmission electron microgram (TEM) characterizations, it was suggested that the second coliphage was most probably related to the Podoviridae family of bacteriophages (Figure $4 \mathrm{~B}$ ).

The coliforms MPN test of Isfahan's municipal wastewater, using three sets of five tubes containing LB culture media, after two hours incubation at $37^{\circ} \mathrm{C}$, showed that all of the 15 tubes were positive regarding turbidity and gas production and the MPN (5-5-5) was measured 
to be 2400 using the MPN standard scale. Addition of phage solution, including both coliphages at a dilution of $10^{-7}$ (phage titer of $2.15 \times 10^{9} / \mathrm{mL}$ ), to MPN series of Isfahan's wastewater, after two hours of incubation at $37^{\circ} \mathrm{C}$, resulted in a significant decline of MPN. The new MPN (5-3-1) was measured to be 110 using the MPN standard scale. The comparison of MPN index of wastewater coliforms before and after treatment with coliphages showed that after two hours of incubation, MPN at 2400 was reduced to 110 , i.e. there was a 22 -fold reduction of coliform's load in wastewater. The incubation of isolated coliphages with municipal wastewater sample in a more realistic thermal condition $\left(22^{\circ} \mathrm{C} \pm 5^{\circ} \mathrm{C}\right)$ resulted more promising outcomes.

The MPN of phage-treated wastewater after two, four and six hours of incubation were 5-3-3, 5-2-2, 4-3-1 and measured 170, 90, 33, respectively. The examination showed that treating the municipal wastewater sample with isolated coliphages resulted in considerable reduction of coliforms so that the MPN after two, four and six hours of treatment declined 14, 26 and 72 times, respectively. The statistical t test of the two independent samples confirmed the effect of bacteriophages on the reduction of coliform's load after treatment of wastewater with coliphage mixture (Tables 1 and 2). According to the data obtained from Leven's test for equality of variances, the decision making criteria is 0.00 and significance (2-tailed) is 0.001 , and is smaller than $5 \%$ so the Null hypothesis is not confirmed. This statistical test indicates that the MPN decline of wastewater coliforms after treatment with coliphages mixture is meaningful.

Figure 1. The spotting of enriched coliphages isolated from Zayandehrood River on the BHA With mix Culture of E. coli SBSWF27 and E. coli PTCC1399 after 24 Hours Incubation at $37^{\circ} \mathrm{C}$ and $120 \mathrm{rpm}$ Aeration Speed

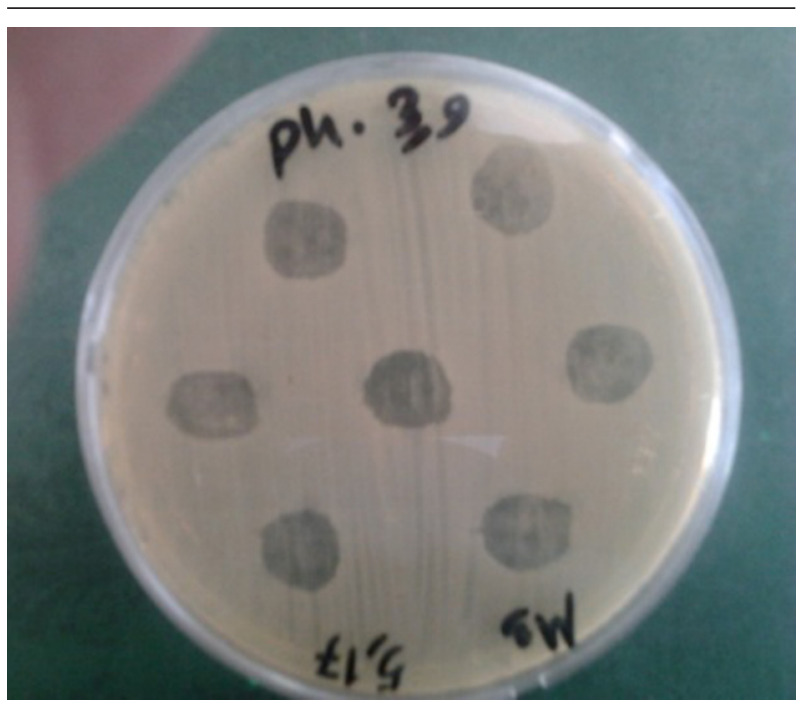

The bacterial lawn was inoculated with different phage dilutions of $10^{-1}$ to $10^{-7}$.

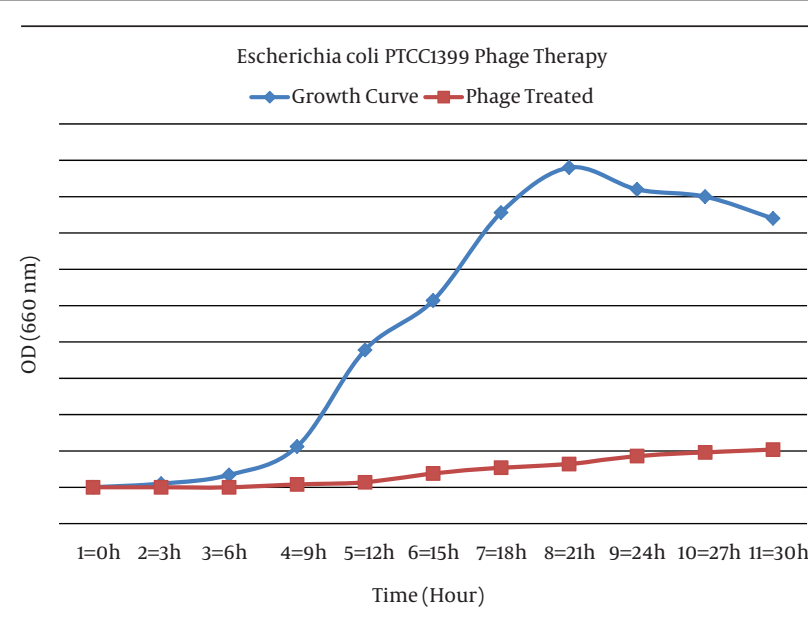

Figure 2. The Growth Curve of E. coli PTCC1399 in the Absence and Presence of Lytic Specific Bacteriophages Isolated From Zayandehrood River During 30 Hours of Incubation at $37^{\circ} \mathrm{C}$

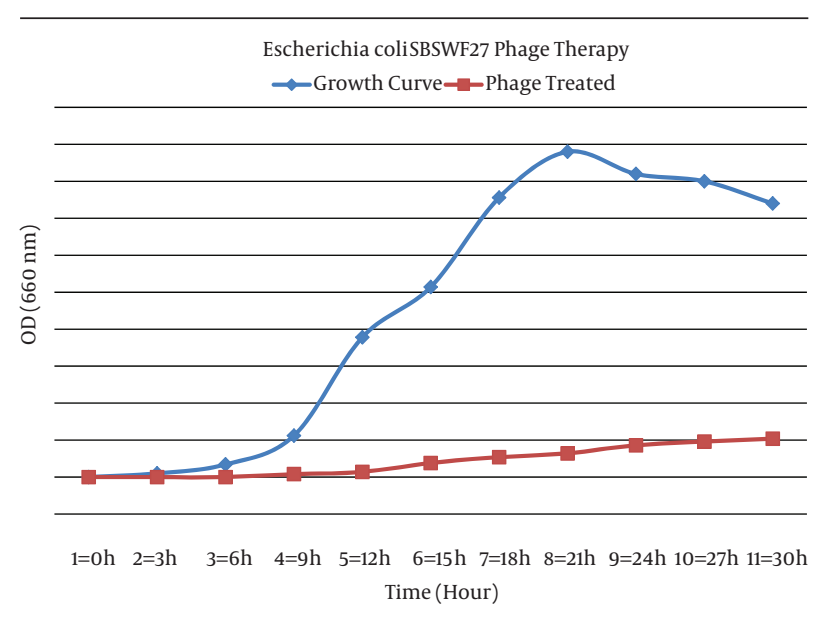

Figure 3. The Comparison Between Normal Growth Curve of E. coli SBSWF27 and Growth Curve After Treatment With Specific Coliphages Isolated From Zayandehrood River During 30 of Hours Incubation at $37^{\circ} \mathrm{C}$

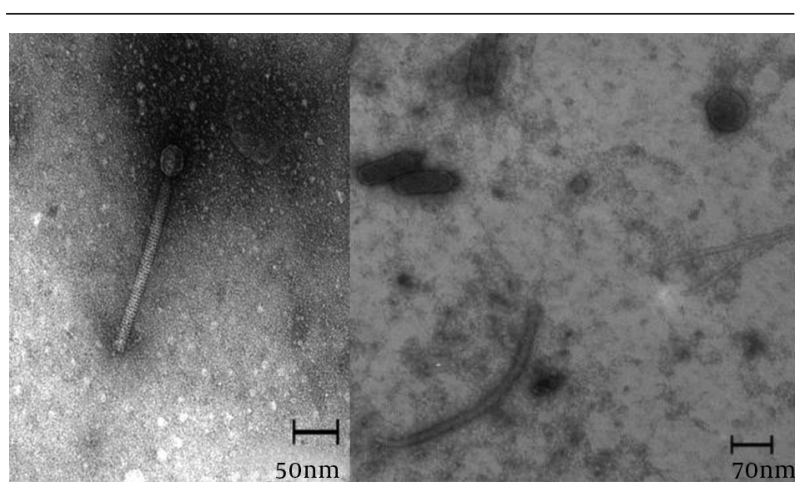

Figure 4. The Transmission Electron Micrograph of the Specific Lytic Bacteriophages of E. coli PTCC1399 and E. coli SBSWF27 Isolated From Zayandehrood River Related to (A) Myoviridae and (B) Podoviridae Family of Bacteriophages 
Table 1. The Effect of Coliphages Isolated From Zayandehrood River on the Reduction of Coliform's Load Using t Test of Group Statis$\operatorname{tics}(\mathrm{N}=11)$

\begin{tabular}{lcc}
\hline Treatment & Mean \pm SD & Standard Error of the Mean \\
\hline OD & & \\
Bacteria & $0.229273 \pm 0.1812397$ & 0.0546458 \\
\hline Phage & $0.021091 \pm 0.0203541$ & 0.0061370 \\
\hline
\end{tabular}

Table 2. The Effect of Coliphages Isolated From Zayandehrood River on the Reduction of Coliform's Load Using t-test of Independent Samples Test

\begin{tabular}{|c|c|c|c|c|c|c|c|c|c|}
\hline & \multicolumn{2}{|c|}{$\begin{array}{c}\text { Levene's Test for } \\
\text { Equality of Variances }\end{array}$} & \multicolumn{7}{|c|}{ t-test for Equality of Means } \\
\hline & \multirow[t]{2}{*}{$\mathbf{F}$} & \multirow[t]{2}{*}{ Sig. } & \multirow[t]{2}{*}{$\mathbf{t}$} & \multirow[t]{2}{*}{ df } & \multirow[t]{2}{*}{ Sig. (2-tailed) } & \multirow[t]{2}{*}{$\begin{array}{l}\text { Mean Dif- } \\
\text { ference }\end{array}$} & \multirow[t]{2}{*}{$\begin{array}{l}\text { Std. Error } \\
\text { Difference }\end{array}$} & \multicolumn{2}{|c|}{$\begin{array}{l}95 \% \text { Confidence Inter } \\
\text { val of the Difference }\end{array}$} \\
\hline & & & & & & & & Lower & Upper \\
\hline \multicolumn{10}{|l|}{ OD } \\
\hline Equal variances assumed & 46.387 & 0.000 & 3.786 & 20 & 0.001 & 0.2081818 & 0.0549893 & 0.0934761 & 0.3228876 \\
\hline Equal variances not assumed & & & 3.786 & 10.252 & 0.003 & 0.2081818 & 0.0549893 & 0.0860653 & 0.3302984 \\
\hline
\end{tabular}

\section{Discussion}

Raghu et al. (2012) have discussed about several roles that bacteriophages play in the environment, biofilm control and water treatment (20). The effect of cyanobacterial specific bacteriophages in preventing bloom has been reported in a previous research (21). There are a few reports suggesting that the normal presence of bacteriophages in sewage could be useful in wastewater treatment especially in activated sludge procedures (22-24). Furthermore, it has been suggested that phages can act as biological tracers of pathogenic bacteria in water and wastewater treatment $(17,18)$. Zumstein et al. studied the interactions of bacterial populations and bacteriophages in anaerobic wastewater treatment using laboratorial anaerobic digesters. They suggested that bacteriophages could influence the dominance of bacterial strains during the process (25). Zhang and $\mathrm{Hu}$ (2013) introduced a combined approach of chlorination and phage therapy for biological control of biofilms created by $P$. aeruginosa on various surfaces. They reported that their combined method could eliminate the bacterial biofilm by up to 95\% - 97\% in two days (26).

Thomas et al. reported the possible application of bacteriophages as antifoam agents in activated sludge systems. They isolated lytic phages related to the family Siphoviridae that could destroy foam producing bacteria (27). Choi et al. (2011) have suggested the biocontrol of sludge bulking in wastewater treatment using lytic bacteriophages. They could control Haliscomenobacter hydrossis, the cause of biomass bulking, and Sphaerotilus natans, the predominant cause of filamentous bulking, in wastewater treatment (28). According to the latest International Committee for Taxonomy of Viruses (ICTV) classification of bacteriophages, Enterobacteriaceae have 982 different bacteriophages among which 344 phages have been re- lated to Myoviridae, 297 phages were members of Siphoviridae and 265 phages were related to Podoviridae (29). Periasamy and Sundaram (2013) have reported the potential of bacteriophages for removal of bacterial pathogens including E. coli in hospital wastewater. They showed that the specific phages of $E$. coli could destroy the bacterial host after 14 hours of incubation (14). So far there is no report addressing the use of coliphages as useful biological control for eliminating or reducing the coliform's microbial load in wastewater treatment. In this research we isolated and identified two novel bacteriophages related to the Myoviridae and Podoviridae families of bacteriophages from Zayandehrood River (Isfahan, Iran) that had lytic effects on E. coli PTCC1399 and E. coli SBSWF27, as an index of coliforms. The latter was isolated and identified from Isfahan municipal wastewater.

The myovirus had a hexagonal head measuring $27.28 \mathrm{~nm}$ and a noncontractile tail measuring $204.5 \times 13.63 \mathrm{~nm}$. The podovirus had an oval head measuring $98 \times 35 \mathrm{~nm}$ and a tail $14 \mathrm{~nm}$ in diameter. These two isolated coliphages did not morphologically match to known myovirus and podovirus that specifically attack E. coli strains (29). The treatment of municipal sewage with the coliphage mixture resulted in a 22-fold decrease of the coliform's MPN from 2400 to 110 after two hours of incubation, a period that could be accessible and amenable in a wastewater treatment plant. The reduction of coliform's population as an important index of wastewater treatment efficacy should be monitored carefully during wastewater treatment procedures (19).

Many WWTPs with the age of 40 - 50 years especially in non-developing countries usually have lost their effectiveness to remove or decrease the number of pathogenic bacteria including coliforms during the treatment pro- 
cess. Thus we suggested that the use of bacteriophages for reduction of pathogenic bacteria in sewage, along with other standard methods in WWTP such as active sludge, could be considered as an effective and simple alternative of costly instruments and establishments of the old WWTP. Also the possibility of phage application in a real WWTP in Isfahan was investigated. There are lagoons in Isfahan WWTP that have been previously used for chlorination of effluents but are now useless. The final effluent could be held for two to four hours and treated with phages before discharge to river and agricultural lands, thus we proposed that the final effluent of a WWTP could be treated with a mixture of coliphages, at a concentration of $1-10 \%$ of coliform's load for one to three hours, to improve the treatment procedure in removing the coliform microbial load at ineffective WWTPs.

The wastewater characterizations such as influent and effluent volume, $\mathrm{pH}$, biological oxygen demand (BOD), chemical oxygen demand (COD), treatment temperature and microbial population as well as coliform's load in the examined city, could be different from several WWTPs in other regions thus the effectiveness of biological control of coliforms by bacteriophages should be monitored for each case specifically. This is the first report of isolation and identification of two novel lytic myovirus and podovirus from Zayandehrood River in Isfahan, that had lytic effects on E. coli PTCC1399 and E. coli SBSWF27 strains as well as coliform's population of Isfahan municipal wastewater. Phage therapy of coliforms using these specific coliphages could be an asset for wastewater treatment and a new approach in the area of modern environmental biotechnology.

\section{Acknowledgements}

We thank Ali Safavi from the School of Veterinary Sciences, University of Shiraz, Iran for his technical assistance in preparing the Transmission Electron Micrographs.

\section{Funding/Support}

This research was funded by an operating grant of the Vice Chancellor of Research of the Falavarjan Branch, Islamic Azad University of Isfahan, Iran.

\section{References}

1. Baggi F, Demarta A, Peduzzi R. Persistence of viral pathogens and bacteriophages during sewage treatment: lack of correlation with indicator bacteria. Res Microbiol. 2001;152(8):743-51.

2. Reid G, Howard J, Gan BS. Can bacterial interference prevent infection? Trends Microbiol. 2001;9(9):424-8.

3. Waldor MK, Friedman DI, Adhya SL. Phages: their role in bacterial pathogenesis and biotechnology.Washington D.C.: ASM Press; 2005.

4. Beheshti Maal K, Bouzari M, Arbabzadeh Zavareh F. Characterization of Two Lytic Bacteriophages of Streptococcus sobrinus Isolated from Caspian Sea. Asian J Biol Sci. 2012;5:138-47.

5. Marks T, Sharp R. Bacteriophages and biotechnology: a review. J Chem Technol Biotechnol. 2000;75(1):6-17.

6. Chanishvili N, Chanishvili T, Tediashvili M, Barrow PA. Phages and their application against drug-resistant bacteria. J Chem Technol Biotechnol. 2001;76(7):689-99.

7. Drozdova OM, An RN, Chanishvili TG, Livshits ML. [Experimental study of the interaction of phages and bacteria in the environment]. Zh Mikrobiol Epidemiol Immunobiol. 1988(7):35-9.

8. Smith HW, Huggins MB, Shaw KM. The control of experimental Escherichia coli diarrhoea in calves by means of bacteriophages. J Gen Microbiol.1987;133(5):1111-26.

9. Soothill JS. Bacteriophage prevents destruction of skin grafts by Pseudomonas aeruginosa. Burns. 1994;20(3):209-11.

10. Beheshti Maal K, Bouzari M, Arbabzadeh Zavareh F. Identification of Streptococcus salivarius bacteriophage isolated from Persian gulf as a potential agent for dental caries phage therapy. Afr J Microbiol Res. 2010;4(20):2127-32.

11. Hennes KP, Simon M. Significance of bacteriophages for controlling bacterioplankton growth in a mesotrophic lake. Appl Environ Microbiol.1995;61(1):333-40.

12. Withey S, Cartmell E, Avery LM, Stephenson T. Bacteriophages-potential for application in wastewater treatment processes. Sci Total Environ. 2005;339(1-3):1-18.

13. Heringa SD, Kim J, Jiang X, Doyle MP, Erickson MC. Use of a mixture of bacteriophages for biological control of Salmonella enterica strains in compost. Appl Environ Microbiol. 2010;76(15):5327-32.

14. Periasamy D, Sundaram A. A novel approach for pathogen reduction in wastewater treatment. J Environ Health Sci Eng. 2013;11(1):12.

15. Wommack KE, Colwell RR. Virioplankton: viruses in aquatic ecosystems. Microbiol Mol Biol Rev. 2000;64(1):69-114.

16. Leong DU, Greisen KS. PCR detection of bacteria found in cerebrospinal fluid. In: Pershing DH, Smith TF, Tenover FC, White T] editors. Diagnostic molecular microbiology: principles and applications.. Washington D.C.: ASM Press; 1993. pp. 300-6.

17. Borrego JJ, Moriñigo MA, de Vicente A, Cornax R, Romero P. Coliphages as an indicator of faecal pollution in water. Its relationship with indicator and pathogenic microorganisms. Water Res. 1987;21(12):1473-80.

18. Abdulla H, Khafagi I, El-Kareem MA, Dewedar A. Bacteriophages in Engineered Wetland for Domestic Wastewater Treatment. Res J Microbiol. 2007;2(12):889-99.

19. Greenberg AE, Clesceri LS, Eaton AD. Standard methods for examination of water and wastewater.Washington D.C.: American Public Health Association; 1992.

20. Raghu HV, Gaare M, Manjunatha BM, Mishra S, Sawale P. Beneficial face of bacteriophages: Applications in food processing. Int J Qual Res. 2012;6(2):101-8.

21. Mole R, Meredith D, Adams DG. Growth and phage resistance of Anabaena sp. strain PCC 7120 in the presence of cyanophage AN-15. J Appl Psychol.1997;9(4):339-45.

22. Hantula J, Kurki A, Vuoriranta P, Bamford DH. Ecology of bacteriophages infecting activated sludge bacteria. Appl Environ Microbiol.1991;57(8):2147-51.

23. Hertwig S, Popp A, Freytag B, Lurz R, Appel B. Generalized trans duction of small Yersinia enterocolitica plasmids. Appl Environ Microbiol.1999;65(9):3862-6.

24. Khan MA, Satoh H, Mino T, Katayama H, Kurisu F, Matsuo T Bacteriophage-host interaction in the enhanced biological phosphate removing activated sludge system. Water Sci Technol. 2002;46(1-2):39-43.

25. Zumstein E, Moletta R, Godon JJ. Examination of two years of community dynamics in an anaerobic bioreactor using fluorescence polymerase chain reaction (PCR) single-strand conformation polymorphism analysis. Environ Microbiol. 2000;2(1):69-78.

26. Zhang Y, Hu Z. Combined treatment of Pseudomonas aeruginosa biofilms with bacteriophages and chlorine. Biotechnol Bioeng. 2013;110(1):286-95.

27. Thomas JA, Soddell JA, Kurtboke DI. Fighting foam with phages? Water Sci Technol. 2002;46(1-2):511-8.

28. Choi J, Kotay SM, Goel R. Bacteriophage-based biocontrol of biological sludge bulking in wastewater. Bioeng Bugs. 2011;2(4):214-7.

29. Ackermann HW. 5500 Phages examined in the electron microscope. Arch Virol. 2007;152(2):227-43. 